\title{
PENGUNGKAPAN CLIMATE CHANGE PADA PERUSAHAAN MANUFAKTUR DI NEGARA ASEAN (Studi Empiris pada Perusahaan Food and Beverage yang Terdaftar di Bursa Efek Negara ASEAN 2013-2014)
}

\author{
Fahri Ali Ahzar 1) \\ Fakultas Ekonomi dan Bisnis Islam, Institut Agama Islam Negeri Surakarta \\ paqriea@gmail.com
}

\begin{abstract}
Climate change is a form of responsibility disclosure of climate change. This study aims to analyze the company's disclosure of climate changes in manufacturing companies in the ASEAN countries. Population of this study is food and beverage company listed in ASEAN stock exchanges. Samples are food and beverage manufacturing company which publishes financial reports and other information in period 2013-2014. The data analysis of this study is content analysis to identify the climate change disclosure by using the Climate Change Disclosure Index. In addition, this study also employees multiple regresion analysis. The result of analysis shows that media exposure, size of the board of directors, and institutional ownership have significant association with climate change disclosure. In contrast, other variables such as state, company size and board size do not have significant association with climate change disclosure

Keywords: climate change disclosure, country, size of company, the media exposure, the size of the board of directors, board size, and institutional ownership
\end{abstract}

\begin{abstract}
ABSTRAK
Climate change disclosure merupakan bentuk tanggung jawab pengungkapan perubahan iklim. Penelitian ini bertujuan untuk untuk menganalisis pengungkapan perubahan perusahaan pada perusahaan manufaktur di negara ASEAN. Populasi yang digunakan adalah seluruh perusahaan food and beverageyag terdaftar di masing - masing bursa efek negara. Sampeldalam penelitian adalah perusahaan manufaktur food and beverageyangmenerbitkan laporan keuangan dan infomasi lain tahun 2013-2014.Analisis data yang digunakan dalam penelitian ini adalah content analysyakni identifikasi pengungkapan perubahan iklim dengan menggunakan Climate Change Disclosure Index terhadap laporan keuangan dan menggunakan regresi. Hasil analisis menunjukkan bahwa terdapat pengaruh antara media exposure, ukuran dewan direksi, dan kepemilikan institusional terhadap climate change diclosure. Negara,ukuran perusahaan, dan ukuran dewan komisaris tidak berpengaruh terhadap climate change diclosure.

Kata kunci : climate change disclosure, negara, ukuran perusahaan, media exposure, ukuran dewan direksi, ukuran dewan komisaris, dan kepemilikan institusional.
\end{abstract}

\section{PENDAHULUAN}

\section{Latar Belakang Masalah}

Salah satu perkembangan baru-baru ini di arena akuntansi sosial dan lingkungan adalah isu perubahan iklim (climate change). Perubahan iklim sebagai isu lingkungan internasional ysng semakin banyak pentingnya dari bagian pemangku kepentingan yang. Perubahan iklim dalam banyak hal mengalami efek buruk pada lingkungan dan manusia. Polusi industri dianggap sebagai salah satu penyebab utama perubahan iklim. Media, pemimpin global, lingkungan hidup, pelanggan, investor dan pemangku kepentingan lainnya mempertimbangkan masalah ini dengan serius. Itu sebabnya, perusahaan menghadapi banyak tantangan untuk membuktikan bahwa mereka berhati-hati tentang pencemaran lingkungan dan melakukan secara bertanggung jawab. Oleh karena itu, banyak perusahaan di seluruh dunia yang mengungkapkan tentang pandangan dan kegiatan yang 
berkaitan dengan isu-isu perubahan iklim dalam laporan tahunan mereka.

Laporan ini diharapkan akan meningkatkan legitimasi mereka di mata masyarakat. Sebagai tren baru dalam pelaporan lingkungan perusahaan, jenis pelaporan telah memperkenalkan beberapa istilah baru, jargon dan wacana. Isu-isu perubahan iklim telah mempengaruhi baik ilmu pengetahuan dan kebijakan iklim (Munasinghe dan Swart, 2005).Perubahan iklim adalah terjadinya perubahan kondisi atmosfer, seperti suhu, san cuaca yang menyebabkan suatu kondisi yang tidak menentu.Perubahan ini sangat berdampak luas bagi kehidupan manusia dalam berbagai sektor.Perubahan iklim juga dapat dikatakan sebagai, keadaan dimana temperatur di bumi mengalami kenaikan dan pergeseran musim. Kenaikan temperatur ini akan menyebabkan terjadinya pemuaian massa air dan permukaan air laut

Perubahan iklim di wilayah Asia Tenggara atau negara anggota ASEAN sudah sangat rentan dampaknya. Eksploitasi sumber daya alam yang merupakan bagian penting dari perekonomian negara ASEAN akibatnya berbagai sektor yang berhubungan dengan pengelolaan sumber daya alam seperti sektor manufaktur berada dalam keadaan yang memprihatinkan karena sumber dayanya terus menipis. Karena berperan penting bagi pembangunan jangka panjang, penanganan masalah lingkungan hidup menjadi semakin mendesak dalam kaitannya dengan isu perubahan iklim. Isu ini menegaskan bahwa perubahan iklim sudah berdampak pada wilayah di beberapa negara anggota ASEAN, sebagaimana dibuktikan oleh peningkatan suhu rata-rata, mperubahan pola curah hujan, kenaikan permukaan laut, dan meningkatnya frekuensi dan intensitas cuaca ekstrim. Perubahan iklim ini memperburuk kekurangan air di banyak bagian wilayah, produksi pertanian, kebakaran hutan dan degradasi, merusak sumber daya pesisir dan kelautan, dan meningkatkan risiko wabah penyakit menular serta berdampak penting pada kegiatan ekonomi di wilayah Asia Tenggara.

Asia Tenggara diproyeksikan akan mengalami dampak buruk yang besar dari perubahan iklim di tahuntahun mendatang. Hasil penelitian dari Asian Development Bank (2009) dalam artikel The Economics of Climate Change in Southeast Asia: A Regional Review menjelaskan bahwa dampak perubahan iklim pada empat negara Asia Tenggara, yaituIndonesia,Filipina, Thailand, dan Vietnam sangat tinggi. GDP global untuk empat negara diproyeksikan akan mencapai $0,6 \%$ pada tahun 2100. Namun ketika empat negara tidak mempertimbangkan dampak non-pasar dan risiko bencana, kerugian PDB rata-rata diperkirakan mencapai $2,2 \%$ pada tahun 2100 . Hal ini dikarenakan empat negara relatif memiliki garis pantai yang panjang, kepadatan penduduk yang tinggi di daerah pesisir, ketergantungan yang tinggi terhadap pertanian dan sumber daya alam, kapasitas adaptasi yang relatif rendah, dan sebagian besar iklim tropis.

Selain Indonesia, Filipina, Thailand, dan Vietnam, Malaysia juga terkena risiko perubahan iklim dan pemanasan global. Tangang, Juneng, Salimun, Sei, Le dan Muhamad (2012) dalam Nazli, Ahmad, Hossainb (2015)menyebutkan bahwa pada akhir abad ke-21 suhu 
permukaan rata-rata Malaysia akan naik 3-5 derajat Celcius.Hal ini menimbulkan banyak efek negatif pada sektor pertanian dari Malaysia. Misalnya, Kementerian Sains Teknologi dan Lingkungan Hidup (2000) dalam Nazli, Ahmad, Hossainb (2015)menyebutkan bahwa ada penurunan $10 \%$ dalam produksi beras untuk setiap kenaikan 10C. Selain itu, perubahan iklim di Malaysia juga akan memiliki efek negatif pada perkebunan kelapa sawit, pengelolaan sumber daya air, sumber daya perikanan, hutan mangrove dan infrastruktur pesisir (Tiong, P Ereira dan Pin,2009 dalam Nazli, Ahmad, Hossainb 2015). Pradini (2013) dalam Jannah 2014 menyatakan bahwa praktik pengungkapan emisi gas rumah kaca termasuk emisi karbon masih minim. Perusahaan yang melakukan pengungkapan emisi karbon memiliki beberapa pertimbangan diantaranya untuk mendapatkan legitimasi dari para stakeholder, menghindari ancamanancaman terutama bagi perusahaanperusahaan yang menghasilkan gas rumah kaca (greenhousegas) seperti peningkatan operatingcosts, pengurangan permintaan (reduceddemand), risiko reputasi (reputational risk), proses hukum (legalproceedings), serta denda dan pinalti (Berthelot dan Robert, 2011).

\section{Rumusan Masalah}

Pengungkapan perubahan iklim (climate change disclosure) merupakan isu yang mulai berkembang di berbagai negara terkait dampak dari perubahan iklim terhadap kelangsungan organisasi tidak terkecuali di Indonesia. Di Indonesia, pengungkapan perubahan iklim merupakan jenis pengungkapan sukarela yang belum banyak organisasi atau entitas bisnis di Indonesia yang mengungkapkan informasi jenis ini. Berdasarkan masalah di atas dapat diidentifikasikan permasalahan sebagai berikut:

1. Apakah negara mempengaruhi pengungkapan perubahan iklim pada perusahaan food and beverage di ASEAN?

2. Apakah size mempengaruhi pengungkapan perubahan iklim pada perusahaan food and beverage di ASEAN?

3. Apakah media exposure mempengaruhi pengungkapan perubahan iklim pada perusahaan food and beverage di ASEAN?

4. Apakahukuran dewan komisaris mempengaruhi pengungkapan perubahan iklim pada perusahaan food and beverage di ASEAN?

5. Apakah ukuran dewan direksi mempengaruhi pengungkapan perubahan iklim pada perusahaan food and beverage di ASEAN?

6. Apakah kepemilikan institusional mempengaruhi pengungkapan perubahan iklim pada perusahaan food and beverage di ASEAN?

\section{Tujuan Penelitian}

Penelitian ini bertujuan untuk memperoleh bukti empiris mengenai hal berikut ini.

a. Praktik pengungkapan perubahan iklim di perusahaan food and beverage di ASEAN.

b. Hubungan negara, size, media exposure, leverage, ukuran dewan komisaris, ukuran dewan direksi, dan kepemilikan institusional terhadap praktik pengungkapan perubahan iklim 
di perusahaan food and beverage di ASEAN

\section{TINJAUAN PUSTAKA}

\section{Landasan Teori}

\section{Teori Legitimasi}

Legitimasi merupakan sistem pengelolaan perusahaan yang berorientasi pada keberpihakan terhadap masyarakat (society), pemerintah individu dan kelompok masyarakat, Gray et al. (1996). Untuk itu, sebagai suatu sistem yang mengutamakan keberpihakan atau kepentingan masyarakat. Dasar pemikiran teori ini adalah organisasi atau perusahaan akan terus berlanjut keberadaannya jika masyarakat menyadari bahwa organisasi beroperasi untuk sistem nilai yang sepadan dengan sistem nilai masyarakat itu sendiri. Teori legitimasi menganjurkan perusahaan untuk meyakinkan bahwa aktivitas dan kinerjanya dapat diterima oleh masyarakat.

Perusahaan menggunakan laporan tahunan mereka untuk menggambarkan kesan tanggung jawab lingkungan, sehingga mereka diterima oleh masyarakat.

Teori legitimasi telah secara ekstensif digunakan untuk menjelaskan motivasi pengungkapan lingkungan secara sukarela oleh organisasi (Pellegrino dan Lodhia, 2012). Hal ini sejalan dengan penelitian O'Donovan (2002) yang menjelaskan bahwa teori legitimasi sebagai faktor yang menjelaskan pengungkapan lingkungan oleh suatu organisasi. Teori legitimasi berasal dari konsep legitimasi organisasi yang telah didefinisikan sebagai suatu kondisi atau status yang ada ketika sistem nilai entitas kongruen dengan sistem nilai dari sistem sosial yang lebih besar dimana entitas adalah bagian. Ketika terdapat perbedaan aktual atau potensial, antara dua sistem nilai, ada ancaman terhadap legitimasi entitas (Dowling dan Pfeffer, 1975 dalam O’Donovan, 2002).

\section{Teori Stakeholder}

Stakeholder adalah semua pihak baik internal maupun external yang memiliki hubungan baik bersifat mempengaruhi maupun dipengaruhi, bersifat langsung maupun tidak langsung oleh peruasahaan. Dengan demikian, stakeholder merupakan pihak internal maupun external, seperti : pemerintah, perusahaan pesaing , masyarakat sekitar, lingkungan internasional, lembaga di luar perusahaan (LSM dan sejenisnya ), lembaga pemerhati lingkungan, para pekerja lingkungan perusahaan, kaum minoritas dan lain sebagainya yang keberadaannya sangat menpengaruhi dan dipengaruhi perusahaan. Stakeholders merupakan individu, sekelompok manusia, komunitas atau masyarakat baik secara keseluruhan maupun secara parsial yang memiliki hubungan serta kepentingan terhadap perusahaan. Kelangsungan hidup perusahaan tergantung pada dukungan stakeholder dan dukungan tersebut harus dicari sehingga aktivitas perusahaan adalah untuk mencari dukungan tersebut. pengungkapan sosial dianggap sebagai bagian dari dialog antara perusahaan dengan stakeholdernya (Gray, et al., 1995). Perusahaan bukanlah entitas yang hanya beroperasi untuk kepentingannya sendiri, dan untuk mendapatkan dukungan dari stakeholder perusahaan harus memberikan manfaat bagi para stakeholdernya. Ghozali dan Chariri (2007) menjelaskan bahwa stakeholders theory mengatakan bahwa perusahaan bukanlah entitas 
yang hanya beroperasi untuk kepentingannya sendiri namun harus memberikan manfaat bagi stakeholder-nya (pemegang saham, kreditor, konsumen, supplier, pemerintah, masyarakat, analis, dan pihak lain).

Hal pertama mengenai teori stakeholder adalah bahwa stakeholder adalah sistem yang secara eksplisit berbasis pada pandangan tentang suatu organisasi dan lingkungannya, mengakui sifat saling mempengaruhi antara keduanya yang kompleks dan dinamis. Hal ini berlaku untuk kedua varian teori stakeholder. Varian pertama berhubungan langsung dengan model akuntabilitas. Stakeholder dan organisasi saling mempengaruhi. Hal ini dapat dilihat dari hubungan sosial keduanya yang berbentukresponsibilitas dan akuntabilitas. Oleh karena itu, organisasi memiliki akuntabilitas terhadap stakeholdernya. Sifat dari akuntabilitas itu ditentukan dengan hubungan antara stakeholder dan organisasi. Teori stakeholder mungkin digunakan dengan ketat dalam suatu organisasi arah terpusat (centered- way organization). Stakeholder theory mengatakan bahwa perusahaan bukanlah entitas yang hanya beroperasi untuk kepentingannya sendiri namun harus memberikan manfaat bagi stakeholder-nya (pemegang saham, kreditor, konsumen, supplier, pemerintah, masyarakat, analis, dan pihak lain). Dengan demikian, keberadaan perusahaan sangat dipengaruhi oleh dukungan yang diberikan oleh stakeholder kepada perusahaan tersebut.

\section{Teori Keagenan}

Teori mengasumsikan keagenan bahwa semua individu bertindak atas kepentingan mereka sendiri dan agen (manajer perusahaan) diasumsikan menerima kepuasan bukan saja dari kompensasi keuangan tetapi juga dari syaratsyarat yang terlibat dalam hubungan keagenan, seperti jumlah waktu luang, kondisi kerja yang menarik, keanggotaan klub dan jam kerja yang fleksibel. Menurut Brigham dan Houston (2006), hubungan keagenan dapat timbul di antara:

a) Pemegang saham dengan manajer. Masalah keagenan dapat timbul jika manajer menempatkan tujuan dan kesejahteraan mereka sendiri pada posisi yang lebih tinggi dari kepentingan pemegang saham. Menurut Jensen dan Meckling (1976), masalah keagenan potensial terjadi bila proporsi kepemilikan atas saham perusahaan kurang dari seratus persen sehingga manajer cenderung bertindak untuk mengejar kepentingannya sendiri dan bukan memaksimalkan nilai perusahaan dalam mengambil keputusan pendanaan. Tindakan manajer yang opoturnistik tersebut akan mempertinggi cost perusahaan dan mengurangi kemakmuran pemegang saham.

b) Pemegang saham (melalui manajer) dengan kreditur. Kreditur memiliki klaim atas sebagian dari arus kas perusahaan untuk pembayaran bunga dan pokok utang. Mereka memiliki klaim atas aset perusahaan saat perusahaan mengalami kebangkrutan. Pada saat perusahaan mengalami kebangkrutan, keputusan harus segera diambil untuk mengatasi 
kondisi tersebut, yaitu apakah akan melikuidasi perusahaan dengan menjual seluruh aset atau melakukan reorganisasi. Manajemen perlu segera bertindak dan khususnya manajer memilih mereorganisasi dengan tujuan mempertahankan pekerjaannya.

\section{Climate Change Disclosure}

Dari sudut pandang bisnis, sikap perusahaan terhadap isu perubahan iklim telah berubah secara signifikan dalam dua dekade terakhir (Kolk, Levy \& Pinkse 2008). Di awal 1990 , bisnis yang sering ditemukan untuk menutupi atau mengabaikan isu perubahan iklim (Deegan \& Haque, 2009). Seiring waktu, tujuan bisnis telah berubah dari penekanan pada kepuasan pemegang saham saja (Friedman, 1962) terhadap saling menguntungkan untuk bisnis dan masyarakat (Freeman, 1984; Jones, 1995). Oleh karena itu, isu perubahan iklim lebih dan lebih dan strategi perusahaan berurusan dengan isu-isu tersebut telah diungkapkan oleh bisnis (Kolk et al, 2008;. Kolk \& Pinkse, 2008). Pengungkapan perubahan iklim juga telah diakui sebagai pendekatan manajemen untuk pengungkapan dan pengendalian risiko perubahan iklim (Kolk \& Pinkse, 2005). Pengungkapan perubahan iklim adalah bagian dari respon perusahaan secara khusus terkait dengan isu perubahan iklim.

Perubahan iklim telah menjadi salah satu topik yang paling penting di bidang pengungkapan sosial dan lingkungan perusahaan (Kolk \& Pinkse, 2008). Secara umum, konsep pengungkapan perubahan iklim baik mencerminkan respon perusahaan publik untuk perubahan iklim dan menunjukkan upaya bisnis yang diterapkan untuk mengelola risiko perubahan iklim. Ada kesepakatan tentang konsep pengungkapan perubahan iklim, perbedaan muncul ketika memutuskan apa yang harus dimasukkan dalam pengungkapan perubahan iklim. Terkait akan kebutuhan dalam pengungkapan perubahan iklim tersebut terdapat organisasi yang mengeluarkan atau membuat idex terkait dengan perubahan iklim yakni Climate Disclosure Standard Board (CDSB). Berdiri sejak tahun 2007, CDSB adalah konsorsium dari 8 organisasi non-pemerintah dan telah mengeluarkan Climate Change Reporting Framework di tahun 2010. Framework ini membantu perusahaan untuk membuat laporan sukarela untuk informasi yang terkait dengan perubahan iklim secara holistik.

\section{Faktor-Faktor yang} Mempengaruhi Climate Change Disclosure

a. Negara

Hubungan antara negara dan kekuasaan sama sekali tidak dapat dipisahkan. Negara merupakan lembaga yang mempunyai kekuasaan tertinggi, dan dengan kekuasaan itu pula negara melakukan pengaturan terhadap masyarakatnya.

b. Ukuran Perusahaan

Size perusahaan merupakan variabelyang banyak digunakan untuk menjelaskan pengungkapan sosial yang dilakukan perusahaan dalam laporan tahunan yang dibuat. Secara umum, perusahaan besar akan mengungkapkan informasi lebih banyak daripada perusahaan kecil. Secara teoritis, perusahaan besar tidak akan lepas dari tekanan politis, yaitu tekanan untuk melakukan 
pertanggungjawaban sosial. Pengungkapan sosial yang lebih besar merupakan pengurangan biaya politis bagi perusahaan (Hasibuan, 2001). Dengan mengungkapkan kepedulian pada lingkungan melalui pelaporan keuangan, maka perusahaan dalam jangka waktu panjang bisa terhindar dari biaya yang sangat besar akibat dari tuntutan masyarakat.

c. Media Exposure

Teori legitimasi secara luas menguji peran yang dimainkan oleh berita media pada peningkatan tekanan yang diakibatkan oleh tuntutan publik terhadap perusahaan. Media mempunyai peran penting pada pergerakan mobilisasi sosial, misalnya kelompok yang tertarik padalingkungan (Patten, 2002). Media juga berperan penting dalam mengkomunikasikan suatu informasi kepada masyarakat.

d. Ukuran Dewan Komisaris

Peran dewan komisaris dalam suatu perusahaan lebih ditekankan pada fungsi monitoring dari implementasi kebijakan direksi. Peran komisaris ini diharapkan akan meminimalkan permasalahan agensi yang timbul antara dewan direksi dengan pemegang saham. Oleh karena itu, dewan komisaris seharusnya dapat mengawasi kinerja dewan direksi sehingga kinerja yang dihasilkan sesuai dengan kepentingan pemegang saham. Fungsi dewan komisaris menurut UU No. 1 tahun 1995 pasal 95-101 tentang Perseroan Terbatas adalah bertugas mengawasi kebijakan direksi dalam menjalankan perseroan serta memberikan nasehat kepada direksi. Dari ketentuan tersebut dapat dikatakan bahwa komisaris memiliki fungsi yang berat,yaitu mengawasi jalannya perseroan sehingga dapat mencapai tujuannya dengan sebaik-baiknya.

e. Ukuran Dewan Direksi

Penelitian Eisenberg et al (1998) yang mencoba menguji ukuran dewan direksi yang lebih sedikit akan berdampak positif terhadap profitabilitas perusahaan menunjukkan korelasi yang negatif antara ukuran dewan direksi dengan tingkat profitabilitas perusahaan dan ukuran perusahaan. Vafeas (2005) yang menguji hubungan antara struktur dewan direksi dan informasi laba menyatakan bahwa jumlah dewan direksi yang lebih sedikit dirasakan akan lebih informatif oleh para partisipan pasar. Hasil penelitian ini juga tidak konsisten dengan hasil penelitian Suranta (2002) dan Suranta dan Midiastuty (2003) yang menemukan hubungan yang positif antara ukuran dewan direksi dan nilai perusahaan. Hasil penelitian ini menunjukkan bahwa semakin besar ukuran perusahaan maka akan semakin besar nilai perusahaan. Hal ini disebabkan adanya upaya pensejajaran kepentingan yang dilakukan oleh manajer dalam kaitannya dengan insentif yang akan diterima oleh manajer perusahaan.

f. Kepemilikan Institusional

Kepemilikan institusional adalah kepemilikan saham perusahaan oleh institusi (badan). Tingkat kepemilikan institusional yang tinggi akan menimbulkan usaha pengawasan yang lebih besar oleh pihak investor institusional sehingga dapat menghalangi perilaku opportunistic manajer (Arif 2006 dalam Machmud \& 
Djaman 2008). Machmud \& Djaman (2008) menyatakan bahwa kepemilikan institusional tidak berpengaruh terhadap pengungkapan tanggung jawab sosial perusahaan. Namun, Nofandrilla (2008) menyatakan bahwa kepemilikan institusional berpengaruh terhadap pengungkapan tanggung jawab sosial perusahaan

\section{Kerangka Pemikiran}

Penelitianini menguji faktor- faktor yang mempengaruhi pengungkapan perubahan iklim pada perusahaan di negara ASEAN. Faktor-faktor tersebut meliputi enam variabel independen yaitu negara, size, investasi, ukuran dewan komisaris, ukuran dewan direksi, kepemilikan institusional. Berdasarkan uraian yang telah dikemukakan sebelumnya, maka variabel yang terkait dalam penelitian ini dapat dirumuskan melalui suatu kerangka pemikiran seperti pada Gambar.

\section{KerangkaPemikiran}

Variable independen

Variable dependen

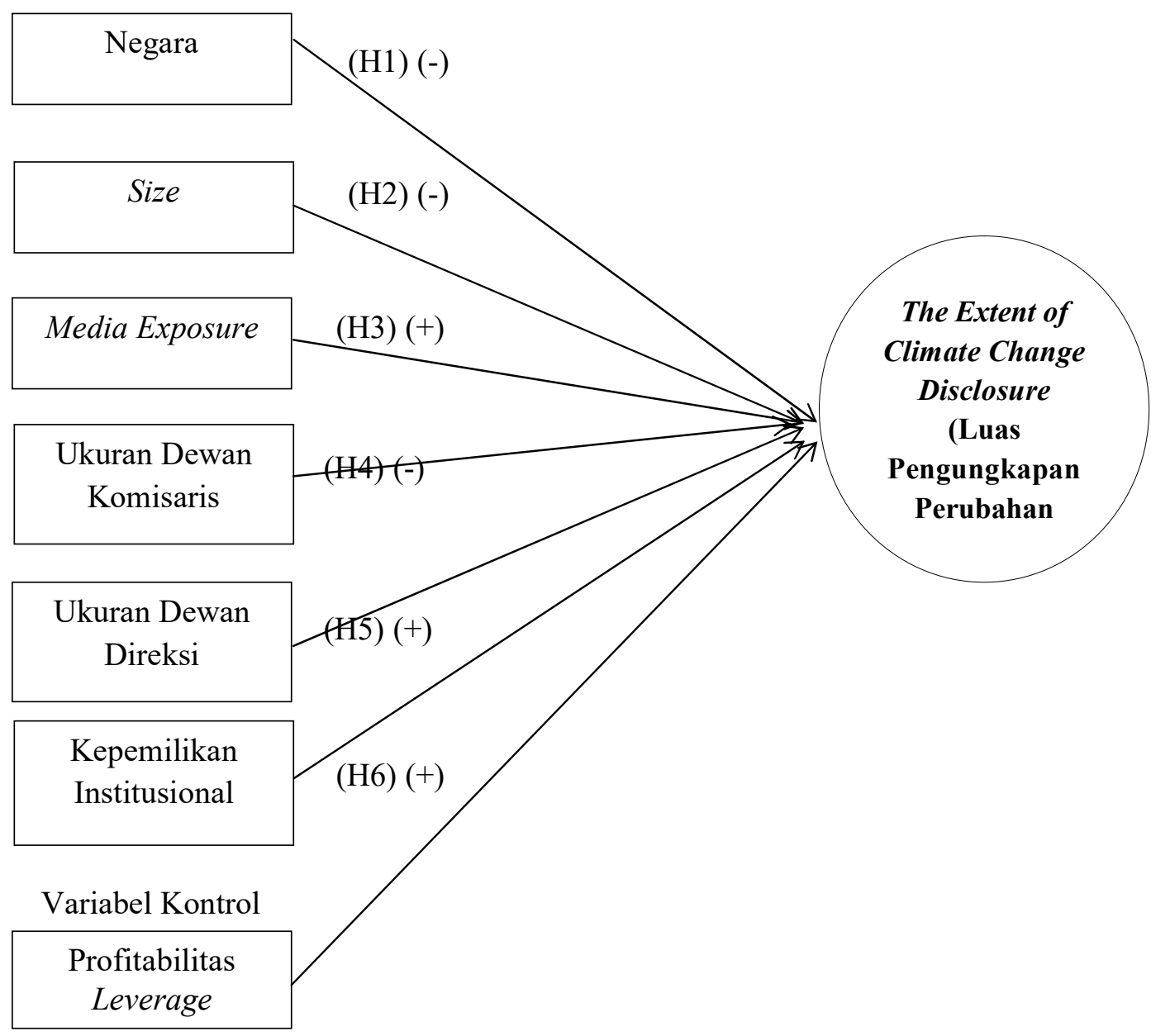




\section{Perumusan Hipotesis}

a. Negara

Yuli (2013), negara-negara maju adalah penghasil emisi gas rumah kaca terbesar di dunia.Hampir setiap tahun, negara maju melepaskan karbondioksida dalam jumlah besar. Tidak hanya negara maju, namun di negara berkembang juga cenderung tinggi walaupun tidak setinggi di negara maju. Berdasarkan penjelasan di atas maka hipotesis yang dibangun adalah:

H1 : Negara berpengaruh terhadap climate change disclosure.

b. Ukuran Perusahaan

Choi et al,(2013) dalam
Jannah (2014) menjelaskan
bahwa ukuran perusahaan
mempunyai hubungan yang
positif dengan pengungkapan
emisi karbon. Perusahaan besar
memiliki tekanan yang lebih
besar dari masalah lingkungan
sehingga mereka cenderung untuk
meningkatkan respon terhadap
lingkungan. Perusahaan besar
lebih didorong untuk
memberikan pengungkapan
sukarela yang berkualitas untuk
mendapatkan legitimasi.
Perusahaan yang besar
diharapkan dapat memberikan
lebih banyak pengungkapan
karbon sukarela. Menurut
penelitian Freedman dan Jaggi
(2005), perusahaan besar lebih
mengungkapkan secara detail
informasi terkait polusi.
Berdasarkan penjelasan di atas
maka hipotesis yang dibangun
adalah:

H2 : Ukuran perusahaan berpengaruh terhadap climate change disclosure.

c. Media Exposure

Pengkomunikasian melalui media akan meningkatkan reputasi perusahaan di mata masyarakat. Pada pelaksanaannya, halinilah yang menjadi bagian pada proses membangun institusi, membentuk norma yang diterima dan praktik legitimasi. Penelitian teori legitimasi secara luas menguji peran yang dimainkan oleh berita media pada peningkatan tekanan yang diakibatkan oleh tuntutan publik terhadap perusahaan. Media mempunyai peran penting pada pergerakan mobilisasi sosial, misalnya kelompokyang tertarik pada lingkungan (Patten, 2002 dalam Reverte, 2008).

Berdasarkan penjelasan di atas maka hipotesis yang dibangun adalah:

H3 : Media exposure berpengaruh terhadap climate change disclosure.

d. Ukuran Dewan Komisaris Proporsi dewan komisaris independen diukur dengan menggunakan indikator persentase anggota dewan komisaris yang berasal dari luar perusahaan dari seluruh ukuran anggota dewan komisaris perusahaan. Keberadaan komisaris independen dalam perusahaan akan mengurangi tindakan manajemen laba.Berdasarkan penjelasan di atas maka hipotesis yang dibangun adalah: 
H4: Ukuran dewan komisaris berpengaruh terhadap climate change disclosure.

\section{e. Ukuran Dewan Direksi}

Penelitian Eisenberg et al., (1998) yang mencoba menguji ukuran dewan direksi yang lebih sedikit akan berdampak positif terhadap profitabilitas perusahaan menunjukkan korelasi yang negatif antara ukuran dewan direksi dengan tingkat profitabilitas perusahaan dan ukuran perusahaan. Vafeas (2000) yang menguji hubungan antara struktur dewan direksi dan informasi laba menyatakan bahwa jumlah dewan direksi yang lebih sedikit dirasakan akan lebih informatif oleh para partisipan pasar. Berdasarkan penjelasan di atas maka hipotesis yang dibangun adalah:

H5: Ukuran dewan direksi berpengaruh terhadap climate change disclosure.

\section{f. Kepemilikan Istitusional}

Midiastuty dan Machfoedz (2003) menemukan hasil positif dan signifikan terkait dengan kepemilikan manajerial. Namun, menurut Boediono(2005) bahwa kepemilikan manajerial memberikan pengaruh yang lemah dan mengindikasikan bahwa tingkat manajerial kurang mampu menjadi mekanisme pengendali. Berdasarkan penjelasan di atas maka hipotesis yang dibangun adalah:

H6: Kepemilikan institusional berpengaruh terhadap climate change disclosure.

\section{METODE PENELITIAN}

Pada bab metode penelitian berisi deskripsi tentang bagaimana penelitianakan dilaksanakan secara operasional. Oleh karena itu, pada bagian ini perludiuraikan hal-hal sebagai berikut: variabel penelitian dan definisi operasional,populasi dan sampel, jenis dan sumber data, metode pengumpulan data dan metode analisis.

\section{A. Jenis dan Metode Pengumpulan Data}

Jenis data yang digunakan dalam penelitian ini adalah data sekunder, yaitu data kuantitatif yang diperoleh dari bursa efek masingmasing negara pada tahun 20132014. Data yang digunakan dalam penelitian ini adalah laporan tahunan dan sustainabilityreport perusahaan untuk periode 2013-2014.

Pengumpulan data dilakukan dengan metode dokumentasi, yaitu menelusuri laporan tahunan dan sustainability report yang terpilih menjadi sampel. Laporan tahunan dan sustainabilityreport diperoleh dari publikasi bursa efek masing-masing negara pada tahun 2013-2014.

\section{B. Populasi, Sampel dan Teknik Pengambilan Sampel}

Populasi dari penelitian ini adalah seluruh perusahaan manufaktur food and beverage yang terdaftar dibursa efek setiap negara pada tahun 2013-2014.

Teknik sampling yang digunakan adalah purposive sampling, yaitu dengan memilih subjek berdasarkan atas ciri-ciri tertentu yang berkaitan dengan karakteristik populasi yang telah memenuhi kriteria yang telah ditetapkan sebelumnya.Adapun kriteria yang digunakan dalam pemilihan sampel 
pada penelitian ini adalah sebagai berikut:

1. Perusahaan manufaktur food and beverageyang terdaftar di masing-masing bursa efek di negaranya

2. Perusahaan memiliki website yang aktif

3. Peneliti dapat memperoleh annual report perusahaan secara berturut selama tahun 2013 sampai dengan tahun 2014

\section{Variabel Penelitian dan \\ Definisi Operasional Variabel}

Dalam penelitian ini, variabel dependen (Y) yang digunakan adalah climate change disclosure, sedangkan variabel independennya terdiri dari negara, size, media exposure, ukuran dewan komisaris, dewan direksi, kepemilikan institusional sebagai variable independen. Variabel kontrol dalam penelitian ini adalah profitabilitas dan leverage. Definisi operasional dan pengukuran untuk variabel-variabel tersebut adalah berikut ini.

1) Climate Change Disclosure

Dalam penelitian ini, climate change disclosure diukur dengan menggunakan beberapa item yang diadopsi dari penelitian Zhonggou (2010). Untuk mengukur sejauh mana pengungkapan perubahan iklim, Zhonggou (2010) mengembangkan checklist dibuat untuk menentukan tingkat pengungkapan sukarela terkait perubahan iklim yang tersedia dalam laporan. Zhonggou (2010) menentukan enam kategori besar yang relevan dengan perubahan iklim sebagai berikut.

a. Board Oversight Indikator ini terkait dengan adanya dewan pengawas yang melakukan pengawasan terhadap perubahan iklim. Pada indikator ini terdapat 3 item, yaitu environmental issues other than carbon emissions and climate change issues, climate change and ghg emission issues, climate change and ghg emission issues.

b. Climate Change Risk Management

Indikator ini berkaitan suatu pendekatan terstruktur dalam mengelola adanya perubahan iklim. Pada indikator ini terdapat 3 item : risk disclosure of climate change, risk management team of climate change, senior executives responsibility.

c. Emission Reduction

Indikator ini berkaitan dengan bagaimana suatu perusahaan dalam mengurangi emisi gas yang dihasilkan oleh tiap perusahaan. Pada indikator ini terdapat 3 item: build or acquireless ghg intensive power plants of climate change, enhanceefficiency of climate change, change fuel of climate change.

d. Carbon Independence Pada indikator ini terdapat 2 item: build or acquire carbon-free power plants of climate change, enhanceefficiency of climate change.

e. Reporting

Indikator ini berkaitan dengan apakah pelaporan perubahan iklim telah sesuai dengan pedoman internasional. Pada indikator 


\section{ini terdapat 1 item yaitu compliance with international gh greporting guide line of climate change. \\ f. External Affairs \\ Indikator ini berkaitan dengan solusi, promosi terkait dengan bagaimana dalam menghadapi perubahan iklim. Pada indikator ini terdapat 3 item: support collaborative solutions of climate change, promote climate friendly behavior of climate change, costto comply with environmental regulations of climate change.}

2) Negara

Negara merupakan suatu wilayah yang memiliki suatu sistem atau aturan yang berlaku bagi semua individu di wilayah tersebut, dan berdiri secara independent.Syarat primer sebuah negara adalah memiliki rakyat, memiliki wilayah,dan memiliki pemerintahan yang berdaulat. Syarat sekundernya adalah mendapat pengakuan dari negara lain.Dalam penelitian ini, negara diukur dengan variabel dummy.Variabel dummy adalah variabel yang digunakan untuk mengkuantitatifkan variabel yang bersifat kualitatif. Variabel dummy merupakan variabel yang bersifat kategorikal yang diduga mempunyai pengaruh terhadap variabel yang bersifat kontinu. Adapun kriteria variabel dummy pada peneilitian ini adalah berikut ini.

$1=$ Untuk negara berkembang.
3) Ukuran Perusahaan Perusahaan dengan aset yang besar dapat dengan mudah mengakses pasar modal. Dengan adanya kemudahan mengakses pasar modal, perusahaan tersebut memiliki fleksibilitas dan kemampuan mendapatkan dana (Puspitasari dan Ernawati,2010). Ukuran perusahaan yang besar cenderung membagikan dividen untuk menghindari konflik keagenan antara pihak manajer dan pemilik (Megginson,1997). Perusahaan besar memiliki kontrol yang lebih baik terhadap kondisi pasar sehingga mereka mampu menghadapi persaingan ekonomi. Selain itu, perusahaan besar memiliki lebih banyak sumber daya untuk meningkatkan profitabilitas perusahaan karena memiliki akses yang lebih baik terhadap sumber- sumber informasi eksternal dibandingkan dengan perusahaan kecil (Wiesantana, 2008).

Berikut rumus ukuran perusahaan (size):

$$
\text { Size }=\text { Ln TotalAset }
$$

4) Media Exposure

Sebagimana penelitian yang dilakukan oleh Aulia (2010), dalam penelitian ini untuk mengukur pengungkapan media juga dilakukan dengan variabel dummy.

Adapun kriteria variabel dummy pada penelitian ini adalah berikut ini.

$$
\begin{aligned}
0= & \text { untuk perusahaanyang } \\
& \text { tidak mengungkapkan } \\
& \text { kegiatan climate change } \\
& \text { disclosure di website }
\end{aligned}
$$




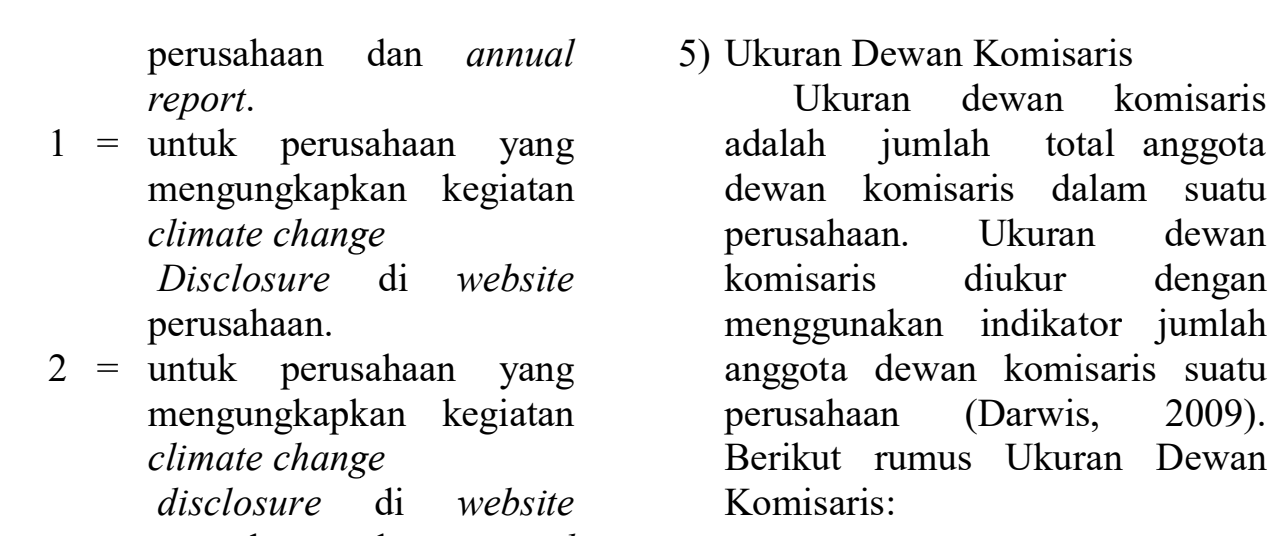

Ukuran Dewan Komisaris $=$ =anggota dewan komisaris

6) Ukuran Dewan Direksi

Beiner et al. (2003) merupakan yang pertama menyimpulkan bahwa jumlah dewan direksi merupakan bagian dari mekanisme corporate governance yang penting, karena dewan direksi dapat memastikan bahwa manajer mengikuti kepentingan dewan. Dalam sistem two tier, terdapat dewan komisaris dan dewan direksi. Dalam mekanisme corporate governance, dewan direksi merupakan pihak yang melakukan fungsi operasional perusahaan sehari-hari. Ukuran dewan direksi diukur dengan jumlah anggota dewan direksi yang ada di dalam perusahaan (Suranta dan Machfoedz, 2003). Berikut rumus Ukuran Dewan Direksi:

\section{Ukuran Dewan Direksi $=\sum$ anggota dewan direksi}

7) Kepemilikan Institusional Menurut Jensen dan Meckling (1976), kepemilikan manajerial dan kepemilikan institusional adalah dua mekanisme corporate governance utama yang membantu mengendalikan masalah keagenan (agencyconflict).

Tingginya kepemilikan institusional akan mendorong aktivitas monitoring karena besarnya pengaruh mereka dalam kebijakan manajemen.
Berikut rumus Kepemilikan Institusional:

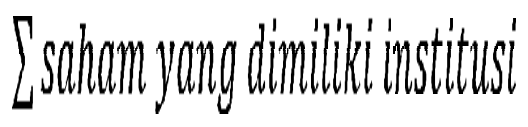

Kepemilikan Institusional $=$

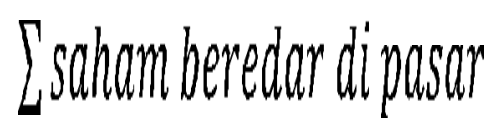

8) Profitabilitas

Profitabilitas diartikan sebagai kemampuan perusahaan untuk menghasilkan laba atau profit 
dalam upaya meningkatkan nilai pemegang saham (Purnasiwi, 2011). Profitabilitas dapat diukur dengan berbagai ukuran diantaranya: ROE, ROA, ROI, NPM. Dalam penelitian ini, profitabilitas diukur dengan menggunakan ROA (Returnon Assets).

9) Leverage

Leverage merupakan perbandingan antara total utang terhadap total aset perusahaan. Perusahaan yang high-leverage akan lebih berhati-hati dalam mengambil tindakan yang menyangkut pengeluaranpengeluaran termasuk tindakan pencegahan dan pengurangan karbon. Pendapat lain mengatakan bahwa semakin tinggi leverage, besar kemungkinan perusahaan untuk melakukan pelanggaran terhadap kontrak utang, sehingga manajer akan melaporkan laba saat ini lebih tinggi dibandingkan laba masa depan (Scott,2000) dalam Ardilla (2011). Dengan laba yang dilaporkan lebih tinggi aka nmengurangi kemungkinan perusahaan melanggar perjanjian utang dan manajer akan memilih metode akuntansi yang akan memaksimalkan laba sekarang.
Leverage $=\frac{\text { Total Utang }}{\text { Total As 尐监t }}$

\section{Uji Regresi}

Data yang telah dikumpulkan dianalisis dengan menggunakan alat analisis statistik, yaitu analisis regresi linear berganda (multiple regression analysis) dengan model persamaan sebagai berikut:

$\mathrm{Y}=\alpha-\beta 1 \mathrm{Neg}-\beta 2 \mathrm{Size}+\beta 3 \mathrm{Me}-$
$\beta 4 U D K+\beta 5 \mathrm{UDD}-\beta 6 K I+e$

Keterangan:

$\mathrm{Y}=$ Climate Change Disclosure.

$\alpha=$ Konstanta.

$\beta 1-\beta 6=$ Koefisien Regresi.

Neg = Negara.

Size = Ukuran Perusahaan.

$\mathrm{Me}=$ Media Exposure.

UDK $=$ Ukuran Dewan Komisaris.

UDD $=$ Ukuran Dewan Direksi.

$\mathrm{KI}=$ Kepemilikan Institusional.

$e=$ error.

\section{Pembahasan}

Penelitian ini menguji praktik climate change disclosure pada perusahaan manufaktur di negara ASEAN. Secara keseluruhan, hasil pengujian hipotesis dapat dilihat pada Tabel berikut ini. 


\begin{tabular}{|c|c|c|}
\hline \multicolumn{3}{|c|}{ Ringkasan Hasil Pengujian Hipotesis } \\
\hline Kode & Hipotesis & Hasil \\
\hline $\mathrm{H}_{1}$ & Negara berpengaruhterhadap climate change disclosure & Ditolak \\
\hline $\mathrm{H}_{2}$ & $\begin{array}{l}\text { Ukuran perusahaan berpengaruhterhadap climate change } \\
\text { disclosure }\end{array}$ & Ditolak \\
\hline $\mathrm{H}_{3}$ & $\begin{array}{l}\text { Media exposure berpengaruhterhadap climate change } \\
\text { disclosure }\end{array}$ & Diterima \\
\hline $\mathrm{H}_{4}$ & $\begin{array}{l}\text { Ukuran dewan komisaris berpengaruhterhadap climate } \\
\text { change disclosure }\end{array}$ & Ditolak \\
\hline $\mathrm{H}_{5}$ & $\begin{array}{l}\text { Dewan direksi berpengaruhterhadap climate change } \\
\text { disclosure }\end{array}$ & Diterima \\
\hline $\mathrm{H}_{6}$ & $\begin{array}{l}\text { Kepemilikan institusionalberpengaruh terhadap climate } \\
\text { change disclosure }\end{array}$ & Diterima \\
\hline
\end{tabular}

Sumber: Hasil pengolahan data

Hipotesis pertama menyatakan bahwa negara berpengaruh terhadap climate change disclosure. Hasil pengujian statistik menunjukkan bahwa nilai koefisien regresi variabel negara adalah -0.029 . Nilai ini signifikan lebih dari 0,05 yaitu 0,643 . Hal ini menunjukkan bahwa negara tidak berpengaruh terhadap climate change disclosure. Peran negara dalam ekonomi ditentukan dari sistem perekonomian dan sistem pengelolaan ekonomi yang mereka gunakan. Sistem perekonomian ini akan sangat ditentukan oleh ideologi yang dianut oleh negara yang bersangkutan. Hal ini akan membedakan peran setiap negara dalam kegiatan perekonomian yang akan tergambar pada kebijakan yang dikeluarkan dalam mengelola perekonomian. Hasil pengujian hipotesis ini menjelaskan bahwa semakin maju dan berkembangnya suatu negara dalam bidang industri maka negara tersebut tidak akan mempenharuhi tingkat kepeduliaannya terhadap kondisi lingkungan.

Hipotesis kedua menyatakan bahwa ukuran perusahaan berpengaruh terhadap climate change disclosure. Hasil pengujian statistik menunjukkan bahwa nilai koefisien regresi variabel ukuran perusahaan adalah -0.012. Nilai ini signifikan lebih dari 0,05 yaitu 0,451 . Hal ini menunjukkan bahwa tidak terdapat pengaruhukuran perusahaan terhadap climate change disclosure. Artinya bahwa perusahaan besar yang dinilai dengan tingkat aktiva yang besar dalam penelitian ini tidak mengungkapkan climate change disclosure yang dilakukan oleh perusahaan. Hasil dari penelitian ini bertentangan dengan teori yang ada dimana teori yang ada menyatakan bahwa perusahaan yang memiliki keagenan yang lebih besar akan mengungkapkan informasi yang lebih luas untuk mengurangi biaya keagenan tersebut. Disamping itu, perusahaan besar merupakan emiten yang paling banyak disoroti dalam pengungkapan yang lebih besar sebagai wujud tanggung jawab sosial.

Hipotesis ketiga menyatakan bahwa media exposure berpengaruh terhadap climate change disclosure. Hasil pengujian statistik menunjukkan bahwa nilai koefisien regresi variabel media exposure 
adalah 1,785 . Nilai ini signifikan pada hasil 0.05 yaitu 0.000 Hal ini menunjukkan bahwa bahwa terdapat pengaruh media exposure terhadap climate change disclosure. Hasil penelitian ini sejalan dengan penelitian yang dilakukan oleh Kristi (2012) bahwa komunikasi perusahaan melalui website mulai banyak digunakan sebagai pelengkap komunikasi melalui media tercetak walaupun belum seluruh potensi website dimanfaatkan oleh perusahaan. Website memungkinkan dialog secara langsung antar pihak. Internet dan websiteakan menjadi media komunikasi yang sangat penting. Media website berperan aktif dengan memberikan riwayat pelaporan dan menyusunnya untuk menggambarkan nilai dari suatu perusahaan . Penelitian oleh Melati (2014) yang menyatakan bahwa pengungkapan melalui media perusahaan memberikan pengaruh terhadap pengungkapan yang dilakukan oleh perusahaan, hasil penelitian tersebut menandakan bahwa pengungkapan informasi melalui media perusahaan (website) mempengaruhi pengungkapan perusahaan sebagai tindakan manajemen untuk diterima dimasyarakat.

$$
\text { Hipotesis }
$$

keempat menyatakan bahwa ukuran dewan komisaris berpengaruh terhadapclimate change disclosure. Hasil pengujian statistik menunjukkan bahwa nilai koefisien regresi variabel ukuran dewan komisaris adalah -0,002.Nilai signifikan lebih dari 0.05 yaitu 0.926 . Hal ini menunjukkan bahwa ukuran dewan komisaris tidak berpengaruh terhadap climate change disclosure. Terdapat beberapa hal yang diduga menjadi alasan mengapa besarnya proporsi dewan komisaris tidak berpengaruh signifikan terhadap pengungkapan.Pertama, dewan komisaris memiliki kompetensi yang masih lemah, padahal kompetensi dewan komisaris memegang peranan penting dalam pengambilan keputusan.Bukan hanya proporsi dewan komisaris yang dipertimbangkan, namun juga pengetahuan dan latar belakang pendidikan sehingga dapat meningkatkan kualitas pengambilan keputusan pada tingkat komisaris terkait dengan climate change disclosure.

Kedua, tidak semua anggota dewan komisaris dapat menunjukkan independensinya sehingga fungsi pengawasan tidak berjalan dengan baik dan berdampak pada kurangnya dorongan terhadap manajemen untuk melakukan pengungkapan. Ketiga, kemampuan dewan komisaris dalam rangka memantau proses keterbukaan dan penyediaan informasi akan terbatas apabila pihak-pihak terafiliasi yang ada di perusahaan lebih mendominasi dan dapat mengendalikan dewan direksi secara keseluruhan. Keempat, dewan lomisaris belum menganggap perlu mengenai ada atau tidaknya pengungkapan climate change disclosure dalam annual report.

Hipotesis kelima menyatakan bahwa dewan direksi berpengaruh terhadap climate change disclosure. Hasil pengujian statistik menunjukkan bahwa nilai koefisien regresi variabel ukuran dewan direksi adalah 0,033 . Nilai signifikan kurang dari 0.05 yaitu 0.041 Hal ini menunjukkan bahwa dewan direksi berpengaruh positif terhadap climate change disclosure. Dengan wewenang yang dimiliki dewan direksi mampu untuk mengarahkan 
manajemen untuk lebih meningkatkan pengungkapan. Hasil ini sesuai dengan penelitan Sam'ani (2008) yang menyatakan peran dewan direksi adalah menentukan kebijakan atau strategi perusahaan baik secara jangka pendek maupun jangka panjang.

Hipotesis keenam menyatakan bahwa kepemilikan institusional berpengaruh terhadap climate change disclosure. Hasil pengujian statistik menunjukkan bahwa nilai koefisien regresi variabel kepemilikan institusional adalah -0.009 . Nilai signifikan kurang dari 0.05 yaitu 0.048. Hal ini menunjukkan bahwa terdapat pengaruh kepemilikan institusionalterhadap climate change disclosure.

Hasil ini sesuai dengan penelitian Novita \& Djakman (2008) menyatakan bahwa struktur kepemilikan institusional umumnya dapat bertindak sebagai pihak yang memonitor perusahaan. Tingkat kepemilikan institusional yang tinggi akan menimbulkan usaha pengawasan yang lebih besar oleh pihak investor institusional sehingga dapat menghalangi perilaku opportunistic manajer (Arif, 2006 dalam Novita \& Djakman, 2008).

Penelitian yang dilakukan Rawi (2008) menyatakan bahwa semakin tinggi tingkat kepemilikan institusional dari persentase saham yang dimiliki oleh investor institusional akan menyebabkan tingkat monitor menjadi lebih efektif. Dengan demikian semakin tinggi tingkat kepemilikan institusional, maka pengungkapan climate change disclosure akan semakin luas dan dapat menjadi pendorong perusahaan untuk melakukan pengungkapan climate change disclosure.
Secara umum, kegiatan climate change disclosure yang dilakukan oleh perusahaan manufaktur di ASEAN mengarah pada indikator board oversight, yakni berkaitan dengan adanya dewan pengawas yang melakukan pengawas terhadap perubahan iklim. Indikator tersebut antara lain meliputi item seperti environmental issues other than carbon emission sand climate change issues, climate change and ghg emission issues, climate change and ghg emission issues. Pengungkapan climate change disclosure yang dilakukan oleh masing-masing negara terlihat bahwa Indonesia sebesar 15\%. Kemudian, Malaysia memperoleh skor dengan mencapai persentase sebesar 35\%. Selanjutnya pada negara Thailand sebesar 17,5\%, dan terakhir pada negara Singapura sebesar $20 \%$.

\section{DAFTAR PUSTAKA}

Ahmad, Nik,.N \& Hossain, Dewan, M. (2015). Climate Change and Global Warming Discourses and Disclosures in the Corporate Annual Reports: A Study on the Malaysian Companies. International Islamic University Malaysia Procedia - Social and Behavioral Sciences. Vol172,pp $246-253$.

Ardilla, M.J. (2011). Faktor-Faktor yang Mempengaruhi Sifat Pengungkapan Sukarela Tanggung Jawab Sosial Perusahaan (Studi Empiris pada Perusahaan yang Terdaftar di Bursa Efek Indonesia) Skripsi. Program Sarjana Jurusan Akuntansi pada Fakultas Ekonomi Undip. Semarang. 
Aulia Zahra Munif. (2010). FaktorFaktor yang Mempengaruhi Indeks Pengungkapan Corporate Social Responsibility di Indonesia (Studi Empiris pada Perusahaan Non Keuangan yang Listing di Bursa Efek Indonesia). Tesis. Fakultas Ekonomi Universitas Diponegoro.

Beiner, S., Drobetz, W., Schmid, F. \& Zimmermann, H. (2003). Is Board Size An Independent Corporate Governance Mechanism. www.ssrn.com (diakses tanggal 29 Mei 2015).

Brigham, E \& Joel, F. Houston. (2006). Dasar- Dasar Manajemen Keuangan. Jilid 1. Edisi Kesepuluh. Jakarta : Salemba Empat.

Darwis. (2009). Corporate Governance Terhadap Kinerja Keuangan.Jurnal Keuangan Dan PerbankanVol 13, No.3. pp. $418-430$

Eisenberg, T., Sundgren,S., Wells, M.T., (1998).Larger Board Size and Decreasing Firm Value in Small Firms. Journal of Financial Economics Vol. 48, No.1, pp. 35-54.

Friedman,M. (1962). Capitalism and Freedom.Chicago:

UniversityofChicagoPress.

Freeman, R. E. (1984). Strategic Management: A Stakeholder Approach. Boston: Pitman.

Ghozali, I \& Chariri, A. (2007). Teori Akuntansi. Semarang: Badan Penerbit Universitas Diponegoro

Gray,R., R. Kouhy, \& S.Lavers. (1995). Corporate Social and Environmental Reporting-A Review of the Literature and A Longitudinal Study of Uk Disclosure. Accounting
Auditing \& Accountability Journal,Vol.8, No. 2, pp.4777.

Gray,R., D.Owen, \& C.Adams.(1996). Accounting and Accountability: Social and Environmental Accounting in A Changing World. Hemel Hempstead: Prentice Hall.

Megginson, (1997). Corporate Finance Theory. Nebraska: University of Omaha AddisonWesley Educational Publisher Inc.

Hasibuan, M. (2001). Manajemen Sumber Daya Manusia:PengertianDasar, Pengertian, dan Masalah. Jakarta: PT. Toko Gunung Agung.

Jensen, M.Cand Meckling,W.H.(1976). Theory of the Firm: Managerial Behavior, Agency Costs and Ownership Structure. Journal of Financial Economics, Oktober, 1976, Vol. 3, No. 4, pp. 305360.Availablefrom:

http://papers.ssrn.com(diakses tanggal 25Mei 2015).

Kolk,A.,D.Levy, \& J. Pinkse. (2008). Corporate Responsesinan Emerging Climate Regime: TheInstitutionalization and Commensuration of Carbon Disclosure. European Accounting Review. Vol. 17, No. 4, pp.719-745

Machmud \& Djakman. (2008). Pengaruh Struktur Kepemilikan Terhadap Luas Pengungkapan Tanggung Jawab Sosial (CSR Disclosure) pada Laporan Tahunan Perusahaan : Study Empiris pada Perusahaan Publik yang Tercatat di Bursa Efek Indonesia 2006.Simposium 


\begin{tabular}{|c|c|}
\hline $\begin{array}{l}\text { Nasional } \\
\text { 11.Pontianak. } \\
\text { Nofandrilla. } \quad(2008) .\end{array}$ & $\begin{array}{l}\text { Usaha.Jurnal Manajemen Teori } \\
\text { dan Terapan UNIMED. Vol. 3, } \\
\text { No.2,hal. 189-215 }\end{array}$ \\
\hline Pengaruh Karakteristik & Rawi \& Muchlish, M. 2010. \\
\hline Perusahaan Terhadap Kebijakan & Kepemilikan Manajemen, \\
\hline Pengungkapan Tanggung Jawab & Kepemilikan Institusi, Leverage \\
\hline Sosial (Studi Empiris pada & dan Corporate Social \\
\hline Perusahaan Pertambangan yang & Responsibility. \\
\hline Terdaftar di Bursa Efek Jakarta. & Nasional Akuntanasi XII. \\
\hline Skripsi Tidak Dipublikasikan. & Purwokerto. \\
\hline Fakultas Ekonomi Universitas & Reverte,C. (2008). Determinantsof \\
\hline Sebelas Maret. Surakarta. & Corporate Social Responsibility \\
\hline O’Donovan. (2002). Environmental & Disclosure Ratingsby Spanish \\
\hline Disclosure in the Corporate & Listed Firms. Journal of \\
\hline Annual Report, Extending the & Business Ethics. Vol 88 No \\
\hline Applicability and Predictive & 2, pp $351-366$ \\
\hline Power of Legitimacy Theory, & Sam'ani.2010. Pengaruh \\
\hline Accounting, $\quad$ Auditing. & Governance dan \\
\hline Accountability Journal, Vol. & Leverage terhadap Kinerja \\
\hline 15, No 3, pp. 344-371 & Keuangan pada Perbankan yang \\
\hline Pellegrino,C. \& Lodhia,S. (2012). & Terdaftar di Bursa Efek \\
\hline Climate Change Accounting & Indonesia (BEI) Tahun 2004- \\
\hline and Australian Mining Industry: & 2007. Tesis Program Studi \\
\hline Exploring the Links between & Magister Manajemen Program \\
\hline Corporate Disclosure and the & Pasca Sarjana. Univesitas \\
\hline Generation of Legitimacy. & Diponegoro \\
\hline Journal of Cleaner & Suranta, Sri. (2002). Dampak \\
\hline Production, Vol. 36, pp 68-82. & Karyawan pada \\
\hline Patten,D.M. (2002). The Relation & Hubungan antara Gaya \\
\hline between Environmental & Kepemimpinan dengan Kinerja \\
\hline Performance & Karyawan Perusahaan Bisnis. \\
\hline Environmental Disclosure: A & Empirika.Vol 15. No 2. pp 116- \\
\hline Research Note. Accounting, & 138 \\
\hline Organizations and & Vafeas, N. (2005). Audit Committees, \\
\hline $\begin{array}{l}\text { Society,Vol.7, No 8, pp.763- } \\
773 \text {. }\end{array}$ & $\begin{array}{l}\text { Boards, and the Quality of } \\
\text { Reported }\end{array}$ \\
\hline Purnasiwi, J.(2011). Analisis & Contemporary \\
\hline $\begin{array}{lr}\text { Pengaruh Size, } & \text { Profitabilitas } \\
\text { dan Leverage } & \text { terhadap }\end{array}$ & $\begin{array}{l}\text { Research. Vol.22, No.4, pp. } \\
\text { 1093-1122. }\end{array}$ \\
\hline Pengungkapan CSR pada & Yuli.(2013). Sekilas \\
\hline Perusahaan yang Terdaftar & Pemanasan Global dan \\
\hline diBursa Efek Indonesia.Skripsi. & Perubahan Iklim \\
\hline Fakultas Ekonomi, Universitas & http://yulifahmi.blogspot.co.id/. \\
\hline Diponegoro, Semarang. & (diakses 16 Oktober 2015). \\
\hline Puspitasari, Filia \& Endang, E. & Zhongguo (Kevin) Pan. (2010). \\
\hline (2010). Pengaruh Mekanisme & Carbon Emission and Climate \\
\hline Corporate Governance terhadap & Change Disclosures in The \\
\hline Kinerja Keuangan Badan & Annual Reports of Chinese \\
\hline
\end{tabular}


INVENTORY

Jurnal Akuntansi, Prodi. Akuntansi - FEB, UNIPMA, Vol. 2, No.2, Oktober 2018

Power Companies:An

Exploration. A Dissertation

Submitted to Auckland

University ofTechnology in
Partial Fulfilment of The

Degree of Master of Business (MBus). 